ISSN 0258-7122

Bangladesh J. Agril. Res. 40(2): 249-257, June 2015

\title{
EVALUATION OF SWEET POTATO GENOTYPES AGAINST SALINITY
}

\author{
FARIDA BEGUM ${ }^{1}$, M. AZIZUL HAQUE ${ }^{2}$ \\ M. S. ALAM ${ }^{3}$ AND H. C. MOHANTA ${ }^{3}$
}

\begin{abstract}
Ten sweet potato lines/varieties were studied for growth response under $\mathrm{NaCl}$ salt stress condition. The rooting ability, in terms of root number, root length and root volume was studied. Growth in terms of root and shoot dry weight was also studied. A variation was recorded among the eight varieties and two lines in different doses of $\mathrm{NaCl}$ for growth responses in terms of rooting ability. The genotypes BARI SP-9, showed rooting ability up to $20 \mathrm{dS}^{-\mathrm{m}}$ among the 10 genotypes. The genotypes BARI SP-2, BARI SP-3, BARI SP-7, BARI SP-9 and line SP-613 showed increase in root number upto $6 \mathrm{dS}^{-\mathrm{m}}$ as compared to control. Accumulation of $\mathrm{Na}^{+}$increased with a concomitant decrease in $\mathrm{K}^{+}$. Sweet potato plantlet transport less amount of $\mathrm{Na}^{+}$and more amount of $\mathrm{K}^{+}$to the shoot. Genotypes BARI SP-7 and BARI SP-9 showed better performance upto15d $\mathrm{S}^{-\mathrm{m}}$.
\end{abstract}

Keywords: Salinity, sweet potato, seedling growth, accumulation of $\mathrm{Na}^{+}$and $\mathrm{K}^{+}$

\section{Introduction}

About 52.8 percent of the net cultivated land in the coastal area is affected by various degrees of salinity in Bangladesh (Karim et. al., 1990). Most of this vast land remains uncultivated. Introduction of salt tolerant crop is one of the most acceptable ways of intensification of crop production in this area. Salt tolerant lines/varieties are needed to be identified for optimum cultivation in coastal areas. Sweet potato is a root crop of Bangladesh covering an area of 7.51 hactre with annual production of 297539 matric tons (BBS, 2011). Sweet potato is a high energy containing but low input crop. Vitamin A deficiency is a major problem in Bangladesh. About $89 \%$ peoples are suffering from vitamin A deficiency (Hossain, 1993). Sweet potato is a rich source of vitamin A as also of starch (Nedunchezhiyan et al., 2007). Farmers can grow sweet potato easily in saline belt. Screening of sweet potato germplasm against salinity is one of the acceptable methods to select better varieties / lines for saline soil. The present study was under taken to evaluate the performance of sweet potato in respect of root growth under $\mathrm{NaCl}$ stress condition because root growth is much more sensitive to salinity than vine growth resulting in low productivity (Greig and Smith, 1962). It is very difficult to maintain a desirable level of salinity under field conditions. As salinity level in field is sporadic, it differs greatly in the same

${ }^{1}$ Plant Physiology Division, Bangladesh Agricultural Research Institute (BARI), ${ }^{2}$ Soil Science Division, BARI, ${ }^{3}$ TCRC, BARI , Bangladesh. 
field (Philip and Bradley, 2001). So, screening of salt tolerant genotype under the field condition is very difficult. Therefore, the present study was done under solution culture to select the better performing varieties/lines of sweet potato against salinity.

\section{Materials and Method}

A laboratory experiment was conducted in Agronomy laboratory, TCRC, to study the root growth initiation, especially the root number; root length and root dry weight. Ten sweet potato genotypes including eight varieties (BARI SP-1, BARI SP-2, BARI SP-4 BARI SP-5, BARI SP-6, BARI SP-7, BARI SP-8 and BARI SP-9) and two promising lines (SP-613 and SP-625) were used in the investigation. Nodal explants $(8-10 \mathrm{~cm})$ of all the genotypes were selected for hydroponics culture in Hoagland nutrient medium. Different doses of $\mathrm{NaCl}$ were applied to prepare the treatment solution. Five levels of salinity viz. $1.8 \mathrm{dS}^{-\mathrm{m}}, 6$ $\mathrm{dS}^{-\mathrm{m}}, 10 \mathrm{dS}^{-\mathrm{m}}, 15 \mathrm{dS}^{-\mathrm{m}}$ and $20 \mathrm{dS}^{-\mathrm{m}}$ were used. Tap water mixed with Hoagland nutrient solution $\left(1.8 \mathrm{dS}^{-\mathrm{m}}\right)$ was considered as control. Salt of $\mathrm{NaCl}$ added to prepare $6 \mathrm{dS}^{-\mathrm{m}}, 10 \mathrm{dS}^{-\mathrm{m}}, 15 \mathrm{dS}^{-\mathrm{m}}$ and $20 \mathrm{dS}^{-\mathrm{m}}$ salinity. Plantlets were grown for two weeks. Root number, root length, root dry weight and shoot dry weight were recorded. Ions were extracted from roots and the shoot by boiling the tissues with distilled water according to the method of Karmoker and Van Steveninck (1978). Amount of $\mathrm{Na}^{+}$and $\mathrm{K}^{+}$were measured using Atomic Absorption Spectrophotometer (Model SpectrAA-55B, Varian).

\section{Results and discussion}

Effect of salinity on root growth and relative root growth in terms of root number, root length and root dry weight.

The mean root number under control was 8.95 which were reduced to 5.75, 3.4, and 0.16 at $10 \mathrm{dS}^{-\mathrm{m}}$, and $15 \mathrm{dS}^{-\mathrm{m}}$ respectively (Table 1). Lower salinity stimulated the root initiation easily in BARI SP-2, BARI SP-3, BARI SP-7, BARI SP-9 and line SP-613. The maximum root number was 14 (BARI SP-8) and the minimum $(3.3 \mathrm{~cm})$ was observed in SP-625 at $6 \mathrm{dS}^{-\mathrm{m}}$. BARI SP-7 also showed better performance under higher salinity like $15 \mathrm{dS}^{-\mathrm{m}}$ (Table 1, Fig.1). Out of ten genotypes, only BARI SP-9 showed rooting ability up to $20 \mathrm{dS}^{-\mathrm{m}}$ (Fig. 1). The mean root number of BARI SP-9 was $1 \mathrm{~cm}$ and mean root length was $9 \mathrm{~cm}$ at 20 $\mathrm{dS}^{-\mathrm{m}}$ salinity.

The mean root length under control condition was $18.38 \mathrm{~cm}$ which was decreased by $14.61 \mathrm{~cm}^{2}$ at $6 \mathrm{dS}^{-\mathrm{m}}, 10.61 \mathrm{~cm}$ at $10 \mathrm{dS}^{-\mathrm{m}}$ and $6.52 \mathrm{~cm}$ at $15 \mathrm{dS}^{-\mathrm{m}}$ salinity (Table 1). Root length of sweet potato decreased with the increase of salinity level though genotype BARI SP-2 showed an initial increase (10\%) in length under lower salinity $\left(6 \mathrm{dS}^{-\mathrm{m}}\right)$ (Table 1, Fig.2) . 


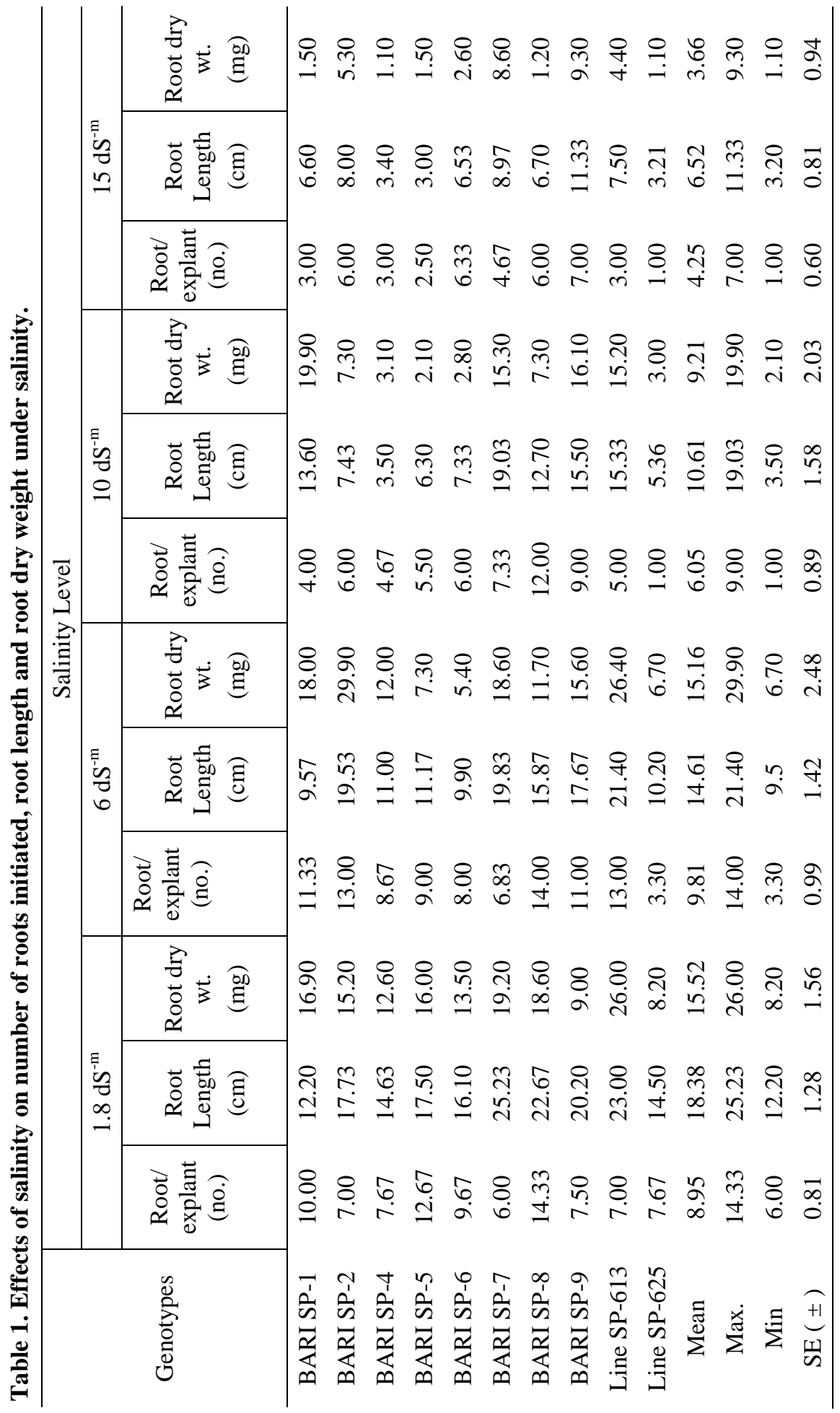




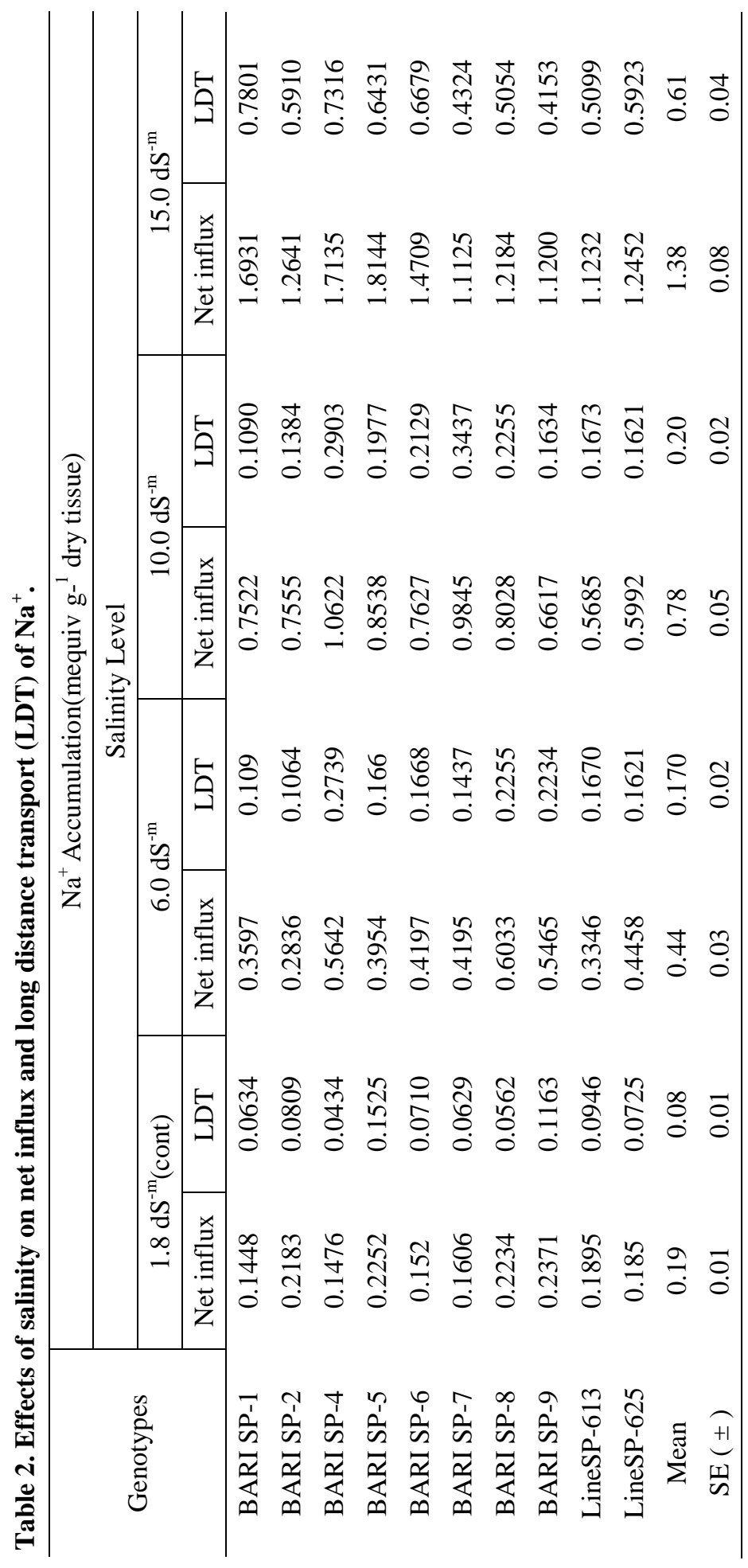


Since at higher salinity $\left(20 \mathrm{dS}^{-\mathrm{m}}\right)$, only one genotype BARI SP-9 out of ten, showed rooting ability, so, effect of salinity at $20 \mathrm{dS}^{-\mathrm{m}}$ is not presented in tables and figures.
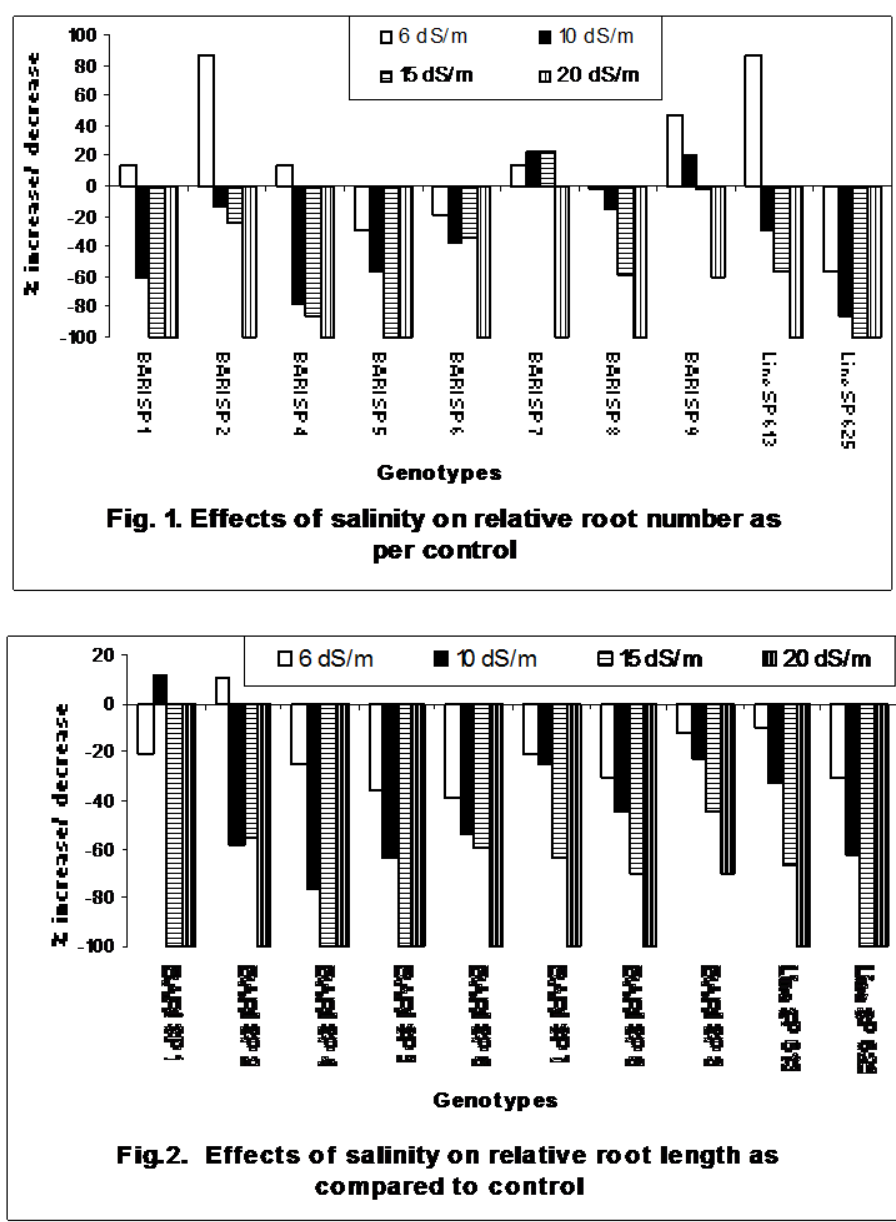

Dry weight of root was presented in Table 1 . The mean root dry weight under control condition $\left(1.8 \mathrm{dS}^{-\mathrm{m}}\right)$ was $15.52 \mathrm{mg}$ which was decreased to $15.16 \mathrm{mg}$ at 6 $\mathrm{dS}^{-\mathrm{m}}, 9.21 \mathrm{mg}$ at $10 \mathrm{dS}^{-\mathrm{m}}$ and $3.66 \mathrm{mg}$ at $15 \mathrm{dS}^{-\mathrm{m}}$ salinity. An initial increase in dry weight was observed in BARI SP-1, BARI SP-2, BARI SP-4 and BARI SP-9 (Table 1, Fig. 3). The variety BARI SP-9 performed better when dry weight was considered (Table 1 and Fig. 3). All the genotypes failed to survive at $20 \mathrm{dS}^{-\mathrm{m}}$ except BARI SP-9. An initial increase in growth in terms of seedling length and dry weight was also observed in maize (Begum et al., 2000) and also in barley (Sultana et al., 1999). An initial increase in biomass was also observed in wheat (Begum et al., 1992, 2008). 


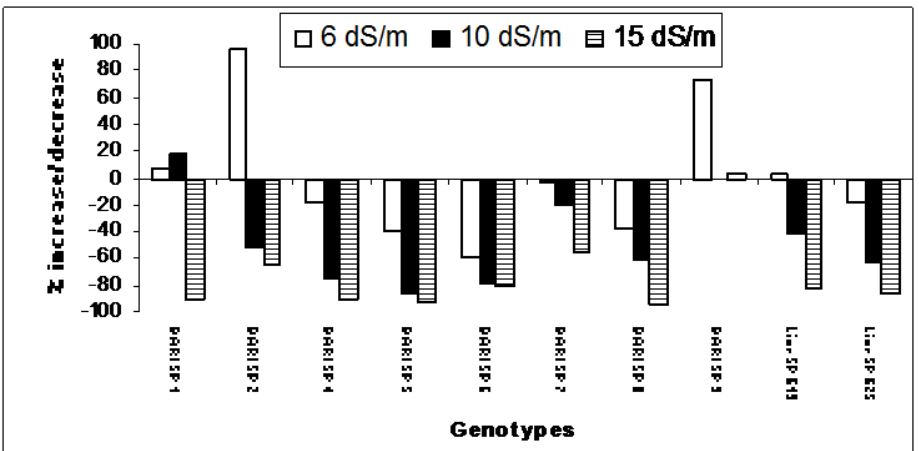

Fig. 3. Effects of salinity on relative root dry weight as compared to control

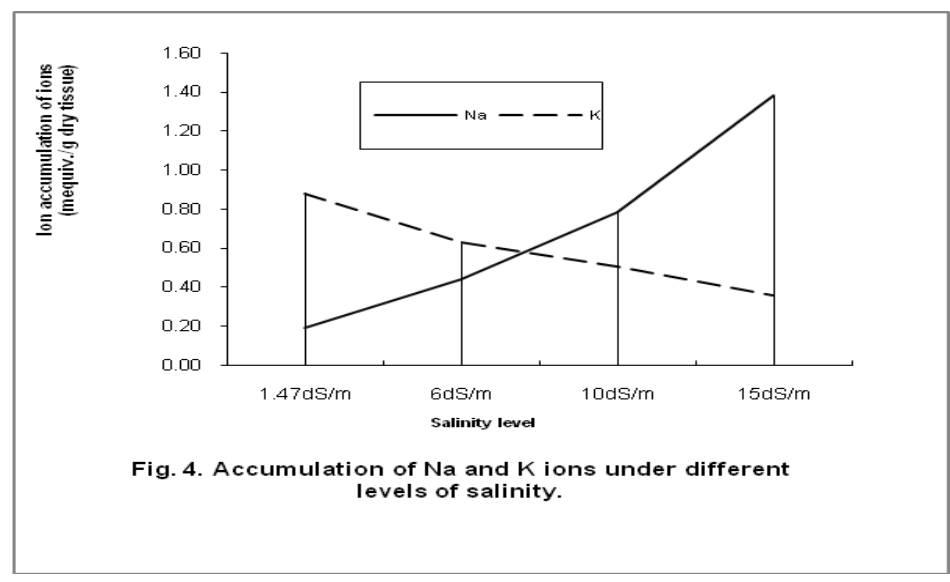

Under salinity stress, the growth was reduced as compared to control. This was because under salinity stress plant needs more energy for its survival, consequently affecting the growth. Similar finding was also observed in case of wheat by Barret-Lennard and his associates (1990), where 3\% to $4 \%$ more energy was found to be needed. Moreover, under salinity condition due to osmotic stress, seeds absorb less water than requirment and the normal activity of the seed was affected and mobility of the seed reserve needed for the growth of seedling was adversely affected (Begum et al, 2010). All these have a cumulative effect and ultimately hampering the seedling growth.

\section{Pattern of ion uptake under salinity in sweet potato genotypes.}

Accumulation of $\mathrm{Na}^{+}$increased in sweet potato genotypes with the increase $\mathrm{NaCl}$ concentration (Table 3). The result is similar with the result observed in maize (Begum et al., 2000), in wheat (Begum et al., 1992) and also in rice (Roy et al., 1995). The mean $\mathrm{Na}^{+}$uptake in the case of control $\left(1.8 \mathrm{dS}^{-\mathrm{m}}\right)$ was 0.19 


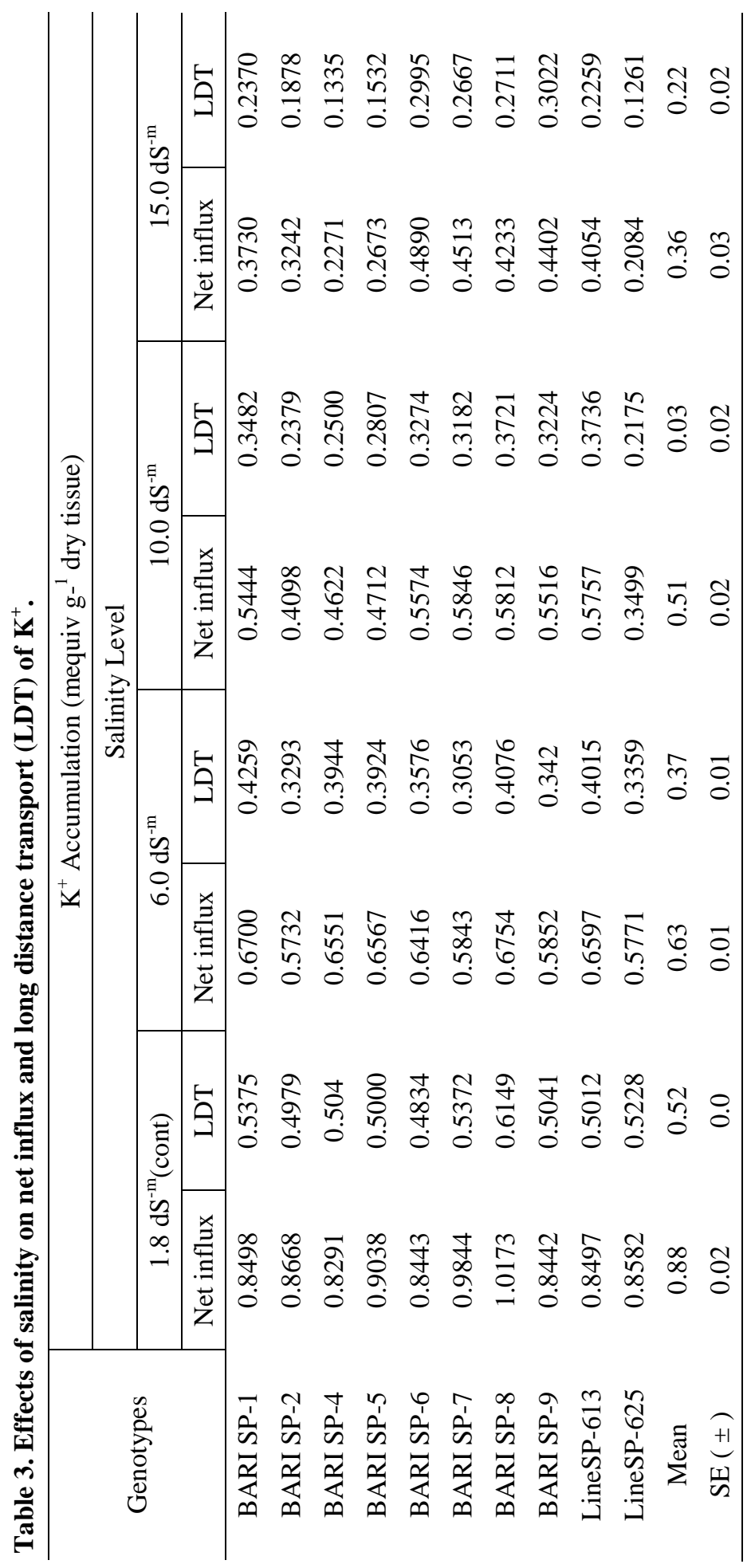


mequiv. $\mathrm{g}^{-1}$ dry tissue which was increased by $0.49,0.89$, and 1.40 mequiv $\mathrm{g}$ ${ }^{1}$ dry tissue with the increase in salinity at 6,10 and $15 \mathrm{dS}^{-\mathrm{m}}$. Under salinity the mean $\mathrm{K}^{+}$uptake by sweet potato plantlet in the case of control was 0.89 mequiv. $\mathrm{g}^{-1}$ dry tissue which decreased by $29 \%, 43 \%$, and $58 \%$ at 6,10 and 15 $\mathrm{dS}^{-\mathrm{m}}$ respectively. It was observed from the result that though sweet potato plantlets accumulate more sodium ions under salinity but it transported less amount of $\mathrm{Na}^{+}$to the shoot. On the other hand, $\mathrm{K}^{+}$decreased with the increase in salinity but the plant tends to maintain $\mathrm{K}^{+}$level in the shoot by transporting more $\mathrm{K}^{+}$to the shoot (Table 3). Under salinity stress condition, maintenance of $\mathrm{K}^{+}$level is essential for plant survival, as most of the physiological activity is going on in the shoot (Datta, 2007). Sweet potato plantlet try to survive by transporting more $\mathrm{K}^{+}$to maintain the $\mathrm{K}^{+}$level in the shoot and less $\mathrm{Na}^{+}$to the shoot as $\mathrm{Na}^{+}$was toxic. From the experiment, an initial increase in growth was also observed in some genotypes. The ions absorbed by the plantlet initially helped in partially overcoming the osmotic stress due to salinity but later on due to their excess accumulation under higher salinity, the plantlets were affected adversely.

Growth is maintained at an appreciable level as long as the cellular $\mathrm{K}^{+} / \mathrm{Na}^{+}$level did not fall below 1 (Huq et. al., 1987). This phenomenon was observed in sweet potato at $8 \mathrm{dS}^{-\mathrm{m}}$ (Fig. 4). The experiment therefore indicated that sweet potato is a moderately salt tolerant crop. The results are very consistant with the result obtained under field condition as reported by Amin et. al., (2011). Amin and his co-workers (2011) observed a 50\% decrease in yield of sweet potato when the salinity level of the field was more than $8 \mathrm{dS}^{-\mathrm{m}}$. The results under laboratory condition also showed that $8 \mathrm{dS}^{-\mathrm{m}}$ salinity was the stress point for sweet potato. These interesting agreements between these two independent experimental findings reinforce the confidence in the results and methodology.

Considering plantlet growth, the sweet potato genotypes like BARI SP-9 and BARI SP-7 are found to be more tolerant to high $\mathrm{NaCl}$ stress and can be included in the varietals improvement program to salt stress conditions.

\section{References}

Amin, M. M., S. Bhuiyan, A. H. M. A. Faisal, I. S. M. Farhad and M. A. Rahaman. 2011. Crop adaptation in saline soils of noakhali: I. Crop performance. 14 (1\&2): 43-52.

Barret-Lennard, Ed. N. Darison and R.P. Galloway. 1990. Plant growth and survival in saline waterlogged soils. W. Aust. Journal of Agriculture. 31: 56-57.

BBS, 2011. Years Book of Agricultural Statistics. Bangladesh Bureau of Statistics, Ministry of Planning, Dhaka, Bangladesh. P. 155. 
Begum, F., B. C. Sarker and S. Hoque. 2000. Effects of salinity on growth and accumulation of $\mathrm{Na}^{+}, \mathrm{K}^{+}$and $\mathrm{Cl}^{-}$in maize (Zea mays). Dhaka Univ. J. Biol Sci. 9(2): 193-198.

Begum, F., J. L. Karmoker, Q.A. Fattah and A.F.M. Maniruzzaman. 1992. The effect of salinity on germination and its correlation in germinating seeds of Triticum aestivum, L. cv. Akber. Plant Cell Physiol. 33(7):1009-1014.

Begum, F., M. Saifuzzaman and W. Sultana. 2008. Evaluation of wheat germplasm against salinity. Bangladesh J. Sci. Ind. Res. 43(2): 223-234.

Begum, F., I. M. Ahmed, A. Nessa and W. Sultana. 2010. The effect of salinity on seed quality of wheat. J. Bangladesh Agril. Univ. 8(1): 19-22.

Barret-Lennard, N. Darison and R.P. Galloway. 1990. Plant growth and survival in saline waterlogged soils. W. Aust. Journal of Agriculture. 31: 56-57.

Datta, C. S. 2007. Assessment of Nutrient Status. In Plant Physiology. New age International Publishers. Pp: 178-180.

Greg, J. K. and F. W. Smith. 1962. Salinity effects on Sweet potato growth. Agron J. 54: 309-313.

Hossain , A.K.M.A. 1993.Importance of vegetables as food security and nutrition, intensive vegetable growing and its utilization. Ed. United States Agency for International Development. P.10.

Huq, S. M. I., J. Gerald and F. Larher. 1987. Growth response of Vicia faba Minor to $\mathrm{NaCl}$ salinity. Bangladesh J. Bot. 16(1): 53-62.

Karim, Z., S. G. Hussain and M. Ahmed. 1990. Salinity problem identification in coastal region of Bangladesh. BARC, Soil Publication No. 33. Pp. 63.

Karmoker, J. L. and R. F. M. Van Steveninck. 1978. Stimulation of volume flow and ion flux by abscisic acid in excised root systems of Phaseolus Vulgare L. cv. Redland Pioneer. Planta. 141:37-43.

Nedunchezhiyan, M. , G. Byju and S. K. Naskar. 2007. Sweet potato (Ipomea batatas L.) as an intercrop in a coconut plantation/growth, yield and quality. J. Root Crops. 33(1): 26-29.

Philip, J. and R. Bradley. 2001. Chloride in soils and its uptake aqnd movement with the plant: A review. Ann. Bot. 88:967-988.

Roy, A., P. Podder and P. K. Shaha. 1995. Salinity induced changes on some cultivars of ice. J. Natt. Bot. Sci. 49:21-25.

Sultana, W., F. Begum, M. Saifuzzaman, A. Nessa and A.B.M. Salahuddin 1999. Salt tolerance of three barley cultivars at early growth stages. Bangladesh J. Sci. and Tech. 1(1): 29-34. 